\section{Sterilisation and the mentally handicapped}

\section{Dear Sirs}

In the first paragraph on the Position Statement on Sterilisation and the Mentally Handicapped by the Section of Psychiatry of Mental Handicap (Psychiatric Bulletin, April 1989, 13, 215) I read:

... "all psychiatrists involved in clinical decisions concerning sterilisation of mentally handicapped people are advised to consult their Medical Defence Unions immediately."

In the third paragraph in relation to mildly mentally handicapped people who are able to give valid consent, the statement adds:

... "for this group the existing procedural arrangements are entirely satisfactory and appropriate."

I wonder if the Section for the Psychiatry of Mental Handicap would like to amend the relevant part of the first paragraph, as follows:

... "all psychiatrists involved in clinical decisions concerning sterilisation of severely mentally handicapped people (or other mentally handicapped people who are unable to give valid consent) are advised to consult their Medical Defence Unions immediately."

In my work with the mentally handicapped people over the past 12 years, I have only twice recommended sterilisation - both couples were mildly mentally handicapped and married with two children and were able to give consent.

I have never yet recommended sterilisation for any severely mentally handicapped person because the need has not arisen.

I personally feel that proper care of mentally handicapped people, counselling of parents, relatives, teachers and other carers and of themselves as far as is practicable, and focusing on contraception, will almost always do away with the need for sterilisation, (Chakraborti, 1987).

I would fully agree that special legislation and arrangements, e.g. the College's recommendations of the establishment of Special Regional Panels, are needed for the sterilisation of severely mentally handicapped people. This would go a long way in cooling the highly charged atmosphere and the intense media interest with the spectre of endless queues of mentally handicapped people waiting to be sterilised!

Park View Resource Centre

D. Chakraborti

King's Lynn PE30 SQD

\section{Reference}

ChakraborTI, D. (1987) Sterilisation and the mentally handicapped. British Medical Journal, 294, 794.

\section{Sexual offences and mental handicap}

\section{DeAr Sirs}

A small proportion of mentally handicapped people pose problems arising from their sexual behaviour, which is more of a socially unacceptable than criminally offending nature and falls in that grey area of 'legal and social' overlap. Delayed sexual and emotional maturation when compounded with limited intellectual and social understanding contributes to such socially unacceptable sexual behaviour as masturbating in public places, exhibiting sexually and in extreme cases bestiality and sexual abuse of small children.

In most cases structured, simplified sex education during adolescence, advice and counselling to parents and relatives, and public awareness and education, would help prevent many such potential sexual problems. This also requires an awareness by the legal profession and police and other statutory and voluntary organisations if these unfortunate 'offenders' are to be prevented from serving prison sentences.

Another dilemma is the inappropriate and undesirable method of tackling such sexual problems by chemical castration - prescribing drugs which inhibit sexual hormones and libido-instead of providing sex education, advice and counselling and social training. A very small proportion of serious and repetitive sexual offenders may need 'chemical' castration but I think such offenders are very rare in the mentally handicapped population.

Proper sex educational and therapeutic services for mentally handicapped people, particularly adolescents and young adults, is the proper, humane and professional way of helping these vulnerable members of society and would prevent many ending tragically, and quite inappropriately, in legal and penal systems.

T. HARI SINGH

Hensol Hospital, Pontyclun, Mid-Glamorgan and

Mental Handicap Services, Llwyneryr Hospital,

Morriston, Swansea

\section{Criteria for consultant posts}

\section{DeAR Sirs}

I read with interest Dr Jolley's letter concerned with the shortfall of numbers of "suitably qualified applicants for consultant posts" both in general psychiatry and psychogeriatrics. (Psychiatric Bulletin, May 1989, 13, 248). However, in his explanations for the situation he failed to mention one possibly significant factor, which is that the College has changed its definition of suitable qualifications. The 1985 JCHPT Handbook makes it clear that three years was the expected length of senior registrar training, and in psychogeriatrics, one year of that period 